\title{
IS THERE A ROLE FOR SIGMOIDOSCOPY IN SYMPTOMATIC PATIENTS? Analysis of a study correlating distal and proximal colonic neoplasias detected by colonoscopy in a symptomatic population
}

\author{
Vítor BINDA¹, Júlio PEREIRA-LIMA¹, Cleber Allem NUNES², Leonardo Torre FALKEIMBERG², \\ Daniel Barcellos AZAMBUJA² and José Vinícius CRUZ²
}

\begin{abstract}
Background - Colonoscopy is the gold standard exam to investigate patients with colonic complaints. However, its availability is limited in developing countries. Sigmoidoscopy has been advocated as a first procedure in colorectal cancer screening strategies, in order to select those who need colonoscopy. Aim - To study the correlation between distal and proximal colonic neoplasias in symptomatic patients 50 years or older and patients 40 to 49 years old who underwent colonoscopy at a gastrointestinal endoscopy unit in 1999 and 2000 with the purpose to evaluate its role in a symptomatic population. Methods - All colonoscopies performed in our Department in 1999-2000 were reviewed. The distal colon was defined as the colonic segment aboral to the splenic flexure. Advanced neoplasias were defined as adenomas larger than 10 millimeters and adenocarcinomas. Results - Of the 2,701 colonoscopies retrieved, 1,125 were enrolled in this study. Prevalence rates for adenoma, advanced adenoma and carcinoma were $28.9 \%, 4.6 \%$ and $4 \%$ in the group of 830 patients 50 years or older (mean age 65 years, 491 women). The finding of one small $(<10 \mathrm{~mm})$ adenoma in the distal bowel doubled the likelihood of finding a proximal neoplasia $(\mathrm{OR}=2.12,95 \% \mathrm{CI}, 1.27-3.54)$, and multiple $(\mathrm{OR}=3.99,95 \% \mathrm{CI}, 1.72-9.28)$ or advanced $(\mathrm{OR}=3.73$, $95 \% \mathrm{CI}, 1.81-7.7)$ adenomas increased this risk even further. Of the patients without adenoma or carcinoma in the distal colon, $1.93 \%$ had proximal advanced neoplasia. In the group of 40 to 49 -year-old patients $(n=395$; mean age 44.8 years, 208 women) the prevalence of adenomas (14.9\%), advanced adenomas (3.4\%), and carcinomas (1.7\%) was lower. Conclusions - The likelihood of finding a proximal lesion is greater in patients with distal neoplasias. This likelihood is further increased when adenomas are multiple or larger than $10 \mathrm{~mm}$. One out of 52 patients 50 years or older with an apparently normal distal colon has advanced proximal neoplasia. Sigmoidoscopy is not an adequate exam for symptomatic patients aged 50 years or older.
\end{abstract}

HEADINGS - Colonoscopy. Sigmoidoscopy. Proctoscopy. Colonic polyps. Colorectal neoplasms. Adenoma.

\section{INTRODUCTION}

The basic indications for colonoscopy are to investigate patients with abdominal complaints, altered laboratory results (anemia, positive fecal occult blood tests), abnormalities in the physical exam or those with a known family history of colorectal cancer. Unfortunately, in countries with limited resources, patients may wait a long time to have their colon completely examined. As there has been discussion about the use of sigmoidoscopy as a screening population tool (by selecting those who should undergo colonoscopy $)^{(47)}$ based on the fact that asymptomatic patients 50 years or older with adenomatous lesions in the distal colon are at a greater risk of having proximal neoplasias ${ }^{(5,9,14,17,19,20,25,28,39,44)}$, it would be important to understand what would happen if the same rationale was applied to a group of patients routinely seen in an outpatient gastrointestinal endoscopy unit. In other words, verify if there is a role for using sigmoidoscopy - an easier, safer and less expensive procedure than colonoscopy $^{(33)}$ - as a first exam in this population.

In this study, we compared the frequency of proximal and distal neoplastic lesions and their correlation in two symptomatic groups of patients: the first composed of

Trabalho realizado nos ${ }^{1}$ Departamentos de Gastroenterologia e de ${ }^{2}$ Coloproctologia da Fundação Faculdade Federal de Ciências Médicas da Santa Casa de Porto Alegre, RS Endereço para correspondência: Dr. Júlio Pereira Lima - Rua Comendador Rheingantz, 910/801 - 90450-020 - Porto Alegre, RS. E-mail: jpereiralima@terra.com.br 
those aged 40 to 49 years, in whom even colonoscopy as a colon cancer screening exam has been thought to be unnecessary ${ }^{(21)}$, and the second aged 50 years or older.

\section{METHODS}

All colonoscopies performed in our Service in 1999 and 2000 were retrieved from a database. In those 2 years, 2,701 procedures were performed by experienced endoscopists or by fellows under supervision using CV-100 videoendoscopes (Olympus Co., Tokyo, Japan). In preparation for colonoscopy, patients were instructed to take three bisacodyl (Dulcolax ${ }^{\bigotimes}$, Boehringer Ingelheim, São Paulo, Brazil) tablets for 2 days before the examination and to be on clear liquids on the day before the procedure. Mannitol (Texon Pharmaceutical Industry Ltda., Viamão, Brazil) was administered for bowel cleansing. All polyps were biopsied or resected. The size and location of the lesions were obtained from the colonoscopy report. The size of polyps was estimated with a biopsy forceps. The histological characteristics of the polyps were obtained from the pathology report. Polyps were classified by their size (larger or smaller than $10 \mathrm{~mm}$ ); polyps larger than $10 \mathrm{~mm}$ and carcinomas identified by histological examination were classified as advanced neoplasias. The proximal colonic segment was defined as the cecum, the ascending colon and the transverse colon, including the splenic flexure. The distal segment, within reach of the sigmoidoscope, was defined as the descending and sigmoid colon and the rectum.

Data were excluded if patients were younger than 40 years $(n=410)$, had an incomplete colonoscopy or inadequate colon preparation $(\mathrm{n}=473)$, had had previous colonic surgery, inflammatory bowel disease or colonic polyposis $(\mathrm{n}=399)$, had undergone colonoscopy or sigmoidoscopy in the 5 years before the examination $(n=63)$, and if polyps were not resected or biopsied $(n=8)$. Also, 223 cases were excluded due to insufficient histopathological information $(n=111)$, incomplete endoscopy reports $(n=10)$, incompatible endoscopy and histology findings $(n=9)$, resected polyps described as normal mucosa or lipoma in histopathological report $(\mathrm{n}=56)$, and missing patient data $(\mathrm{n}=37)$.

The study population was composed of 1,125 patients that underwent colonoscopy due to abdominal pain, change in bowel habits (mainly constipation), anemia and weight loss. Family history of colorectal cancer or polyps was not routinely recorded. The analysis of findings was performed separately for patients younger and older than 50 years.

The proximal and distal colonic segments were classified according to the presence of hyperplastic, adenomatous polyps or cancer. The most advanced lesion in each segment was classified as the segment's main lesion. Patients with adenomas in the distal segment were classified into three groups: one single polyp $<10 \mathrm{~mm}$; more than one polyp $<10 \mathrm{~mm}$; and one or more polyps $\geq 10 \mathrm{~mm}$. Considering the proportion of adenomatous polyps and advanced neoplasias in the proximal colonic segment of patients whose distal segment was apparently normal (without any polyp or cancer), we determined the crude and adjusted odds ratios (OR) and the relative risk of proximal neoplasias according to the groups defined above. We also stratified results by age and sex.
Statistical comparisons between groups were calculated with the method of ANOVA (analysis of variance) and Fisher's exact test. Multivariate logistic-regression analysis was used to identify the individual contribution of each independent variable (distal findings, age and sex) in the outcome, expressed through the calculated OR. Probability values of $P<0.05$ were regarded as statistically significant.

\section{RESULTS}

Of the 1,125 patients included in the study, 295 were 40 to 49 years old (mean age: $44.8 ; 208$ women) and 830 were 50 years or older (mean age: 65.01; 50-96; 491 women). Polyps were identified in 453 colonoscopies $(40.26 \%)$ and cancer in 38 $(3.37 \%)$. The histological diagnoses of colonic polyps and the location of colon cancers are shown in Table 1. The distribution of cases according to different types of polyps or cancer and their locations are shown in Table 2. Table 3 shows the adjusted OR for proximal neoplasia according to the patient's age, sex and distal findings at colonoscopy.

\section{a) Patients aged 50 years or older $(\mathbf{n}=\mathbf{8 3 0})$}

In this group, 240 patients $(28.9 \%)$ had 374 adenomatous polyps (mean 1.56 polyps/patient): 334 polyps $(89,3 \%)$ had up to $10 \mathrm{~mm}$ in size and $40(10.7 \%)$ were larger than $10 \mathrm{~mm}$. The number of adenomas significantly increased with ageing $(P=0.006)$; the frequency of advanced adenomas also increased, but has not reached statistical significance $(P=0.3)$.

The prevalence rate for adenomas was $28.9 \%$ (240/830), and for advanced adenomas, $4.6 \%$. These results did not change when patients with cancer were excluded from calculations: the prevalence rate for adenomas was $28.6 \%(228 / 797)$, and for advanced adenomas, $4.64 \%$ (37/797). Adenomas were found more often in men than in women $(36.6 \%$ vs. $23.6 \%, P<0.001)$.

Adenomas or cancer were found in 261 patients $(31.44$ $\%)$. Of these, 12 had cancer and at least one adenoma; in 6 of them, the adenoma was found in the same colonic segment ( 5 in the distal and 1 in the proximal segment). The prevalence rate of any neoplasia was $31.44 \%$, and of advanced

TABLE 1. Distribution of polyps, advanced neoplasias and cancer according to age groups

\begin{tabular}{lcc}
\hline & \multicolumn{2}{c}{ Patients } \\
\cline { 2 - 3 } & $\begin{array}{c}40-49 \text { years } \\
(\mathbf{n}=295)\end{array}$ & $\begin{array}{c}50 \text { and older } \\
(\mathbf{n}=830)\end{array}$ \\
\hline Patients with polyps & $89(30.1 \%)$ & $364(43.9 \%)$ \\
Inflammatory & $29(9.8 \%)$ & $79(9.5 \%)$ \\
Juvenile & $0(0)$ & $5(0.6 \%)$ \\
Hyperplastic & $33(11.2 \%)$ & $116(14 \%)$ \\
Adenomatous & $44(14.9 \%)$ & $240(28.9 \%)^{*}$ \\
Patients with advanced neoplasias & $14(4.74 \%)$ & $70(8.43 \%)^{* *}$ \\
(including cancer) & & \\
Proximal/distal & $2 / 12$ & $17 / 55 * * *$ \\
Patients with cancer & $5(1.7 \%)$ & $33(4 \%)$ \\
Proximal/distal & $0 / 5$ & $7 / 26$ \\
\hline$* P<0.001$ & & \\
$* * * 0.039$ & & \\
$* * *$ Two patients with advanced neoplasias in both segments & &
\end{tabular}


TABLE 2. Distribution of patients according to colorectal findings and location

\begin{tabular}{|c|c|c|c|c|c|c|c|c|c|c|}
\hline \multirow{3}{*}{ Distal colon } & \multicolumn{10}{|c|}{ Proximal colon } \\
\hline & \multicolumn{2}{|c|}{$\begin{array}{l}\text { Normal } \\
(\mathrm{n})\end{array}$} & \multicolumn{2}{|c|}{$\begin{array}{l}\text { Non-advanced adenomas } \\
(\mathrm{n})\end{array}$} & \multicolumn{2}{|c|}{$\begin{array}{l}\text { Advanced adenomas } \\
\text { (n) }\end{array}$} & \multicolumn{2}{|c|}{$\begin{array}{c}\text { Cancer } \\
(\mathrm{n})\end{array}$} & \multicolumn{2}{|c|}{$\begin{array}{c}\text { Total } \\
\text { (n) }\end{array}$} \\
\hline & $<50 \mathrm{yr}$ & $\geq 50 \mathrm{yr}$ & $<50 \mathrm{yr}$ & $\geq 50 \mathrm{yr}$ & $<50 \mathrm{yr}$ & $\geq 50 \mathrm{yr}$ & $<50 \mathrm{yr}$ & $\geq 50 \mathrm{yr}$ & $<50 \mathrm{yr}$ & $\geq 50 \mathrm{yr}$ \\
\hline Normal & 227 & 516 & 13 & 78 & 1 & 7 & 0 & 4 & 241 & 605 \\
\hline Hyperplastic polyps & 21 & 53 & 2 & 11 & 0 & 1 & 0 & 1 & 23 & 66 \\
\hline \multicolumn{11}{|c|}{ Non-advanced adenomas } \\
\hline Single & 11 & 63 & 2 & 20 & 1 & 1 & 0 & 0 & 14 & 84 \\
\hline Multiple & 3 & 12 & 2 & 7 & 0 & 0 & 0 & 1 & 5 & 20 \\
\hline Advanced adenomas & 4 & 19 & 3 & 8 & 0 & 1 & 0 & 1 & 7 & 29 \\
\hline Cancer & 5 & 20 & 0 & 6 & 0 & 0 & 0 & 0 & 5 & 26 \\
\hline Total & 271 & 683 & 22 & 130 & 2 & 10 & 0 & 7 & 295 & 830 \\
\hline
\end{tabular}

TABLE 3. Likelihood of proximal neoplasia according to distal colorectal findings, age and sex

\begin{tabular}{lccc}
\hline \multirow{2}{*}{ Distal segment } & \multicolumn{3}{c}{ Adjusted OR for proximal neoplasias** } \\
\cline { 2 - 4 } & OR & CI & P \\
\hline Normal $^{*}$ & 1 & -- & -- \\
Only hyperplastic polyps & 1.34 & $0.73-2.45$ & 0.33 \\
Single $<10$ mm adenomatous polyp & 2.12 & $1.27-3.54$ & 0.004 \\
More than one $<10$ mm adenomatous polyp & 3.99 & $1.72-9.28$ & 0.001 \\
At least one $>10$ mm adenomatous polyp & 3.73 & $1.81-7.7$ & $<0.001$ \\
Cancer & 1.41 & $0.56-3.59$ & 0.461 \\
Age $\geq 50$ years & 2.13 & $1.34-3.39$ & 0.001 \\
Male & 1.93 & $1.37-2.7$ & $<0.001$ \\
\hline
\end{tabular}

* No cancer or adenomatous or hyperplastic polyps in distal colonic segmen

neoplasia, 8.4\%. Most patients $(65.1 \%, 170 / 261)$ had only one neoplasia detected by colonoscopy: $42.9 \%(73 / 170)$ in the proximal and $57.1 \%(\mathrm{n}=97 / 170)$ in the distal segment Of the patients with advanced neoplasias, 60\% (42/70) had one single lesion: 8 patients $(19 \%)$ in the proximal and 34 $(80.1 \%)$ in the distal segment.

Of the patients with an apparently normal distal segment, $1.81 \%(11 / 605)$ had an advanced neoplasia in the proximal colon. When patients with hyperplastic polyps were included in this group of patients with an apparently normal distal colon, this prevalence rate increased to $1.93 \%$ (13/671). Most of these 13 patients were older than 60 years $(77 \%$ - mean age: 67.77 \pm 10.06 years; range: $53-85$ ).

b) Patients aged 40 to 49 years $(n=295)$

In this group, 44 patients (14.9\%) had adenomatous polyps, 10 of which (3.4\% of the sample) were classified as advanced. Five patients (1.7\%) had cancer, all of them in the distal segment. Of the 70 adenomas resected (mean 1.59 polyp/patient), 60 $(85.7 \%)$ were up to $10 \mathrm{~mm}$ in size and $10(14.2 \%)$ were larger than $10 \mathrm{~mm}$. Of the patients with an apparently normal distal segment, $0.41 \%(1 / 241)$ had advanced neoplasia in the proximal colonic segment; this rate was lower than in the older group, but the difference was not statistically significant $(P=0.13)$.

\section{DISCUSSION}

The prevention of colon cancer is highly feasible because its precursor lesion, the colonic polyp, is easily recognized and

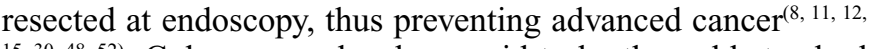
$15,30,48,52)$. Colonoscopy has been said to be the gold standard for colon cancer screening and prevention because it examines the colon thoroughly, and the precursor lesions can be resected at the same time ${ }^{(13,35,45)}$. On the other hand, some authors suggest the use of flexible sigmoidoscopy alone or together with fecal occult blood screening, referring screened patients to colonoscopy only in selected cases ${ }^{(7,38,50)}$. They argue that the cost and the risk of sigmoidoscopy is lower, and that it has a greater availability, since physicians and non-physicians are able to perform $i^{(18)}$. On the other hand, authors who contend in favor of colonoscopy state that the indication of sigmoidoscopy, instead of full colonic examination, is the same as to indicate unilateral mammography ${ }^{(35)}$.

LIEBERMAN et al. ${ }^{(27)}$ reported that patients with unspecified abdominal complaints frequently underwent colonoscopy, and that their rate of major colonic disease was not higher than that of asymptomatic patients. This similar frequency rates of colonic disease in symptomatic and asymptomatic individuals is not surprising, since almost all colonic polyps are symptomless, and cancer usually turns out to be symptomatic at an advanced stage. This finding led us to wonder what would happen on our daily practice if we use sigmoidoscopy in its ideal form, that is, the one that reaches the proximal descending colon, as a first exam.

In this study, adenomas and advanced adenomas were found in $28.9 \%$ and $4.6 \%$ of the patients 50 years or older. This prevalence rate was not affected by the frequency of colon cancer in this symptomatic population, that is, these figures did not change after the exclusion of adenocarcinomas. SUNG et al. ${ }^{(49)}$ studied a Chinese asymptomatic population and described a prevalence of $20.2 \%(102 / 505)$ for adenomas and 3.8\% (19/505) for adenomas larger than $10 \mathrm{~mm}$. REX et al. ${ }^{(44)}$ found a prevalence rate of $34.7 \%$ (42/121) for adenomas and 2.5\% (3/121) for advanced adenomas in a study of asymptomatic African Americans. ANDERSON et al. ${ }^{(2)}$ found a prevalence rate of $10.2 \%$ for important neoplasias (adenocarcinomas, advanced adenomas or more than two adenomas) in an asymptomatic population screened for colon cancer. Studies published more than a decade ago also showed variable prevalence rates in different populations ${ }^{(22,26,40)}$. NEUGUT et al. ${ }^{(31)}$ conducted a comprehensive review of studies about the prevalence of neoplasia, and found rates ranging from $8.4 \%$ to $54.9 \%$ for adenomas, and from $0.5 \%$ to $2.2 \%$ for adenocarcinomas 
detected by colonoscopy in a screening setting. Such variability should not be exclusively assigned to populational differences, but may also be explained by different definitions of advanced adenomas, and by a higher diagnostic yield, at least for smaller lesions, in recent years due to improvements in colonoscopes and colonoscopy techniques.

In our study, adenomas were found more often in men, which confirms findings reported in other studies ${ }^{(20,42,51)}$. In accordance with previous published data ${ }^{(17,20,42,51)}$, adenoma frequency was also significantly greater for older patients.

The inclusion of symptomatic patients is an important difference from other studies because symptomatic patients lead to a greater diagnostic rate of cancers, but not of adenomas, as almost all patients with adenomas are asymptomatic. Although a trend towards proximal migration of colonic cancer has been described in the literature ${ }^{(10,23,29,37)}$, we found that $79 \%$ of the cancers diagnosed in our study were within the reach of the sigmoidoscope. HAMMER et al. ${ }^{(17)}$ found 59 invasive carcinomas in their series, $50 \%$ in the distal segment; PATEL et al. ${ }^{(34)}$ reported that $8.5 \%$ of 189 carcinomas were right-sided only.

Excluding patients with cancer, the proportions of patients with proximal and distal adenomas were similar. It is important to note, however, that advanced adenomas were located in the distal colon in most patients, and this association remained when patients with cancer were included in the analysis. GRANQVIST et al. ${ }^{(16)}$ reported that small polyps $(\leq 5 \mathrm{~mm})$ are uniformly distributed in the colon, while most larger polyps are located distally. NICHOLSON et al. ${ }^{(32)}$ retrospectively studied 1,131 asymptomatic patients and found that $12 \%$ had adenomas, $62 \%$ of which in the distal segment, $25 \%$ in the proximal segment, and $14 \%$ in both segments. In their study, however, mean age was relatively low (54 years, range: 40 to 78 ), which may explain the lower prevalence of adenomas and the lower rate of proximal findings.

Our study confirmed that distal lesions in symptomatic individuals increase the patient's risk of having proximal lesions. As observed in other studies about colon cancer screening, the likelihood of having a proximal polyp increased with single, multiple or advanced adenomas $(>10 \mathrm{~mm})^{(20,28)}$. When compared with patients without a distal lesion, patients 50 years or older with a distal adenoma less than $10 \mathrm{~mm}$ were twice as likely to have a proximal lesion. In patients with two or more lesions or with advanced lesions, the likelihood of having proximal neoplasms increased more than threefold. These data are similar to those reported by LIEBERMAN et al. ${ }^{(28)}$ and IMPERIALE et al. ${ }^{(20)}$ for advanced lesions. We have not found any statistically significant increase in the risk of proximal lesions in patients with distal cancer, which might have been due to a type II statistical error.

In our sample, the diagnosis of a hyperplastic polyp in the rectum or sigmoid was not associated with proximal lesions. Similar investigations reported conflicting findings ${ }^{(1,3,20,28)}$. However, most well-designed studies point out that hyperplastic polyps are not associated with an increased risk of neoplasia ${ }^{(6,36,41,46)}$.

Most advanced lesions were found in the distal colon in our study. Therefore, if our patients had initially undergone sigmoidoscopy, and colonoscopy had only been indicated for patients with a neoplasia in the distal colon or rectum, $1.93 \%$ of the patients with an apparently normal distal segment $(1.56 \%$ of all the patients examined) would have been released with an undiagnosed advanced proximal neoplasia. LIEBERMAN et al. ${ }^{(28)}$ and IMPERIALE et al. ${ }^{(20)}$ reported similar results, and found advanced neoplasias in $2.7 \%$ and $1.5 \%$ of the asymptomatic patients with an apparently normal distal segment.

Most advanced proximal neoplasias (13/17; 76.5\%) were not associated with a sentinel distal lesion, that is, no findings within the reach of the sigmoidoscope indicated proximal lesions. REX et al. ${ }^{(43)}$ examined patients with proximal adenocarcinomas and did not find any distal neoplasias in $65.5 \%$ of the cases. SUNG et al. ${ }^{(49)}$ reported that $53.8 \%$ of asymptomatic individuals with proximal advanced neoplasias had no distal lesions. Data from population screening studies conducted by LIEBERMAN et al. ${ }^{(28)}$ and IMPERIALE et al. ${ }^{(20)}$ suggested that about $50 \%$ of all advanced proximal neoplasias would have been missed if the finding of an adenomatous polyp at sigmoidoscopy were the criterion to refer patients to colonoscopy. These figures should be viewed with caution, since they may be underestimated, as they are based on the skill of the operator to reach the splenic flexure with a small instrument, a task that is not successfully achieved very often ${ }^{(43)}$. No more than three-fourths of all patients have a complete examination of the sigmoid colon when the endoscope is inserted up to $60 \mathrm{~cm}$, and only a small number of patients have the descending colon evaluated by sigmoidoscopy ${ }^{(24)}$.

If the finding of an adenoma at sigmoidoscopy was the criteria to refer patients to colonoscopy, an endoscopist that performs 100 sigmoidoscopies in patients older than 50 years a month would let 23 patients with proximal advanced lesions go undiagnosed per year. There is an important difference in professional liability when dealing with symptomatic or asymptomatic individuals. Asymptomatic patients may either undergo colon cancer screening or not. In patients with abdominal complaints, however, the failure to diagnose an advanced lesion in 1 out of every 52 cases examined, as would be the case if patients first underwent sigmoidoscopy instead of colonoscopy, is much more consequential, in terms of medical liability, than missing this type of case in a screening program. In screening procedures, only the cases that are diagnosed are accounted for. In clinical practice, however, missed cases should be seriously accounted for. Thus, the examination of the distal colon alone may be enough when screening an asymptomatic population (taking the number of lives saved in an otherwise unscreened population), but its role in evaluating a symptomatic patient should be viewed with caution, although in the vast majority of the cases, patients' complaints have no relationship to an advanced polyp.

The criterion used in this study to define an advanced neoplasia was its size $(\geq 10 \mathrm{~mm})$, but not its histological subtype or its grade of dysplasia. Polyp size is not the sole criterion to define

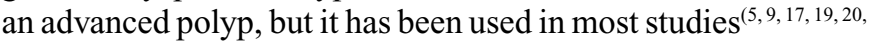
$25,28,39,44)$. Moreover, it is the only criterion objectively available for the endoscopist at the time of sigmoidoscopy or colonoscopy. BETES-IBANEZ et al. ${ }^{(5)}$ reported that the predictive ability of 
models using endoscopic data alone was similar to that found in models that included histopathological data. In addition, histological subtype and grade of dysplasia correlate with polyp size $^{(12)}$, and less than one tenth of polyps smaller than $10 \mathrm{~mm}$ are villous or tubulovillous ${ }^{(4)}$.

American medical literature stresses the importance of colon cancer screening for individuals older than 50 years, but not for those aged 40 to 49 years. We found a prevalence rate of $14.9 \%$ for adenomas in this group, a rate that is similar to the one found by IMPERIALE et al. ${ }^{(21)}$ in an asymptomatic population. In our study, the finding of a proximal advanced adenoma with a normal distal colon was almost 5 times less likely in this group than in patients 50 years or older. Before concluding that this could be acceptable (one missing case in every 244 sigmoidoscopies), it must be remembered the meaning of a misdiagnosis in a young person.

\section{CONCLUSION}

In summary, in this study of a Brazilian symptomatic population, adenoma prevalence rates were similar to those found in Europe and North America. Finding adenomas within the reach of the flexible sigmoidoscope increased the likelihood of finding proximal lesions. This risk was greater for older patients and those with multiple distal or advanced neoplasias. Although the prevalence of lesions was higher in the distal colon, one in every 52 patients without neoplasia in the distal colon had advanced lesions in the proximal colonic segment, and three-fourths of the patients with proximal advanced lesions had an apparently normal distal segment. Thus, sigmoidoscopy should not be considered adequate to investigate symptomatic patients over 50 years-old.

Binda V, Pereira-Lima J, Nunes CA, Falkemberg LT, Azambuja DB, Cruz JV. Há espaço para a retossigmoidoscopia na avaliação de pacientes sintomáticos? Análise da relação entre a presença de neoplasias colônicas proximais e distais em uma população sintomática submetida a colonoscopia. Arq Gastroenterol. 2007;44(1):2-7.

RESUMO - Racional - A colonoscopia é o exame padrão-ouro na investigação de pacientes com sintomas intestinais baixos. Entretanto, sua disponibilidade é restrita em países com poucos recursos financeiros. Objetivo - Como a retossigmoidoscopia flexível tem sido defendida como o primeiro procedimento em estudos de rastreamento populacional para o câncer de cólon e reto, selecionando aqueles que necessitam colonoscopia, estudou-se a correlação entre a presença de neoplasias proximais e distais nos pacientes com idade entre 40 e 49 anos e naqueles com idade igual ou superior a 50 anos submetidos a colonoscopia, objetivando avaliar o papel deste exame segmentar em uma população sintomática. Métodos - Todas as colonoscopias realizadas no Departamento de Coloproctologia do Complexo Hospitalar da Santa Casa de Porto Alegre, RS, no período de 2 anos, foram retrospectivamente estudadas. O cólon distal foi definido como o segmento colônico aboral à flexura esplênica. Neoplasias avançadas foram definidas como adenomas com tamanho superior a $1 \mathrm{~cm}$ ou adenocarcinomas. Resultados - Das 2701 colonoscopias realizadas naquele período, 1125 foram incluídas no estudo. Destas, 830 foram feitas em pacientes com idade igual ou superior a 50 anos (média de idade de 65 anos, 491 mulheres) e a prevalência de adenomas, adenomas avançados e carcinoma foi $28,9 \%$, $4,6 \%$ e $4 \%$, respectivamente. A presença de um adenoma pequeno $(<1 \mathrm{~cm})$ no cólon distal dobrou a probabilidade de coexistir uma neoplasia proximal (RC $=2.12$, IC 1.27-3.54), sendo este risco maior quando os adenomas eram múltiplos $(\mathrm{RC}=3.99, \mathrm{IC} 1.72-9.28)$ ou avançados $(\mathrm{RC}=3.73$, IC 1.81-7.7). Entre os pacientes com o segmento colônico distal livre de adenomas ou carcinomas, 1,93\% apresentavam neoplasias proximais avançadas. No grupo de pacientes com idade entre 40-49 anos ( $n=395$; média de idade 44,8 anos, 208 mulheres), a prevalência de adenomas (14,9\%), adenomas avançados $(3,4 \%)$ e carcinomas $(1,7 \%)$ foi menor. Conclusões - A presença de neoplasias distais aumenta a probabilidade de serem encontradas lesões proximais. Esta probabilidade é ainda maior quando são encontrados adenomas múltiplos ou maiores do que $1 \mathrm{~cm}$. Um, em cada 52 pacientes com o segmento distal livre de neoplasias, apresenta neoplasia avançada no segmento colônico proximal. A retossigmoidoscopia flexível não é exame adequado para investigação de pacientes sintomáticos com idade superior a 50 anos.

DESCRITORES - Colonoscopia. Sigmoidoscopia. Proctoscopia. Pólipos do cólon. Neoplasias colorretais. Adenoma. 


\section{REFERENCES}

1. Abeyasundara H, Hampshire P. Hyperplastic polyposis associated with synchronou adenocarcinomas of the transverse colon. ANZ J Surg. 2001;71:686-7.

2. Anderson JC, Alpern Z, Messina CR, Lane B, Hubbard P, Grinson R, Ells PF, Brand DL. Predictors of proximal neoplasia in patients without distal adenomatous pathology. Am J Gastroenterol. 2004;99:427-7.

3. Ansher AF, Lewis JH, Fleischer DE, Cattau EL Jr, Collen MJ, O'Kieffe DA, Korma LY, Benjamin SB. Hyperplastic colonic polyps as a marker for adenomatous colonic polyps. Am J Gastroenterol. 1989;84:113-7.

4. Bacellar MS, Bonno AA, Baraviera AC, Almeida MG, Kiss D. Estudo histológico de pólipos menores que $5 \mathrm{~mm}$ ressecados por colonoscopia. Rev Bras Coloproctol. 2000;20:158-61

5. Betes-Ibanez M, Munoz-Navas MA, Duque JM, Angos R, Macias E, Subtil JC, Herrai M, de la Riva S, Delgado-Rodriguez M, Martinez-Gonzelez MA. Diagnostic value of distal colonic polyps for prediction of advanced proximal neoplasia in an average-risk population undergoing screening colonoscopy. Gastrointest Endosc. 2004;59:634-41.

6. Brady PG, Straker RJ, McClave SA, Nord HJ, Pinkas M, Robinson BE. Are hyperplastic rectosigmoid polyps associated with an increased risk of proximal colonic neoplasms? Gastrointest Endosc. 1993;39:481-5.

7. Burt RW. Colon cancer screening. Gastroenterology. 2000;119:837-53.

8. Citarda F, Tomaselli G, Capocaccia R, Barcherini S, Crespi M. Efficacy in standard clinical practice of colonoscopic polypectomy in reducing colorectal cancer incidence. Gut. 2001;48:812-5.

9. Collett JA, Platell C, Fletcher DR, Aquilia S, Olynyk JK. Distal colonic neoplasms predict proximal neoplasia in average-risk, asymptomatic subjects. J Gastroenterol Hepatol. 1999;14:67-71.

10. Cucino C, Buchner AM, Sonnenberg A. Continued rightward shift of colorectal cancer Dis Colon Rectum. 2002;45:1035-40

11. DiSario JA, Foutch PG, Mai HD, Pardy K, Manne RK. Prevalence and malignan potential of colorectal polyps in asymptomatic, average-risk men. Am J Gastroenterol. 1991;86:941-5.

12. Eide TJ. Natural history of adenomas. World J Surg. 1991;15:3-6

13. Fletcher RH. Screening colonoscopy: option or preference? Gastrointest Endosc. 2000;51:624-7.

14. Gondal G, Grotmol T, Hofstad B, Bretthauer M, Eide TJ, Hoff G. Grading of dista colorectal adenomas as predictors for proximal colonic neoplasia and choice of endoscope in population screening: experience from the Norwegian Colorectal Cance Prevention Study (NORCCAP). Gut. 2003;52:398-403.

15. Gordon PH, Nivatvongs S. Principles and practice of surgery for the colon, rectum, and anus. 2nd ed. St. Louis, Mo: Quality Medical Publishing: 1999.

16. Granqvist S. Distribution of polyps in the large bowel in relation to age. A colonoscopic study. Scand J Gastroenterol. 1981;16:1025-31.

17. Hammer K, Hammer J, Oesterreicher C, Potzi R. Advanced distal colonic lesion as predictors of advanced lesions in the proximal colon. Medicine (Baltimore) 2000;79:127-34.

18. Horton K, Reffel A, Rosen K, Farraye FA. Training of nurse practitioners and physician assistants to perform screening flexible sigmoidoscopy. J Am Acad Nurse Pract. 2001;13:455-9.

19. Ikeda Y, Mori M, Miyazaki M, Yoshizumi T, Maehara Y, Sugimachi K. Significance of small distal adenoma for detection of proximal neoplasms in the colorectum. Gastrointest Endosc. 2000;52:358-61.

20. Imperiale TF, Wagner DR, Lin CY, Larkin GN, Rogge JD, Ransohoff DF. Risk of advanced proximal neoplasms in asymptomatic adults according to the distal colorecta findings. N Engl J Med. 2000;343:169-74.

21. Imperiale TF, Wagner DR, Lin CY, Larkin GN, Rogge JD, Ransohoff DF. Result of screening colonoscopy among persons 40 to 49 years of age. N Engl J Med. 2002;346:1781-5.

22. Johnson DA, Gurney MS, Volpe RJ, Jones DM, VanNess MM, Chobanian SJ, Avalos JC, Buck JL, Kooyman G, Cattau EL Jr. A prospective study of the prevalence of colonic neoplasms in asymptomatic patients with an age-related risk. Am J Gastroenterol. 1990;85:969-74

23. Kee F, Wilson RH, Gilliland R, Sloan JM, Rowlands BJ, Moorehead RJ. Changing site distribution of colorectal cancer. BMJ. 1992;305:158

24. Kronborg O. Colon polyps and cancer. Endoscopy. 2000;32:124-30.

25. Levin TR, Palitz A, Grossman S, Conell C, Finkler L, Ackerson L, Rumore G, Selby JV. Predicting advanced proximal colonic neoplasia with screening sigmoidoscopy. JAMA. 1999;281:1611-7.

26. Lieberman DA, Smith FW. Screening for colon malignancy with colonoscopy. Am J Gastroenterol. 1991;86:946-51.

27. Lieberman DA, de Garmo PL, Fleischer DE, Eisen GM, Chan BK, Helfand M Colonic neoplasia in patients with nonspecific GI symptoms. Gastrointest Endosc. 2000;51:647-51
28. Lieberman DA, Weiss DG, Bond JH, Ahnen DJ, Garewal H, Chejfec G. Use of colonoscopy to screen asymptomatic adults for colorectal cancer. Veterans Affairs Cooperative Study Group 380. N Engl J Med. 2000;343:162-8.

29. Mensink PB, Kolkman JJ, Van Baarlen J, Kleibeuker JH. Change in anatomic distribution and incidence of colorectal carcinoma over a period of 15 years: clinical considerations. Dis Colon Rectum. 2002:45:1393-6.

30. Murakami R, Tsukuma H, Kanamori S, Imanishi K, Otani T, Nakanishi K, Fujimoto I, Oshima A. Natural history of colorectal polyps and the effect of polypectomy on occurrence of subsequent cancer. Int J Cancer. 1990;46:159-64.

31. Neugut AI, Jacobson JS, Rella VA. Prevalence and incidence of colorectal adenomas and cancer in asymptomatic persons. Gastrointest Endosc Clin N Am. 1997;7:387-99.

32. Nicholson FB, Korman MG, Stern AI, Hansky J. Distribution of colorectal adenomas: implications for bowel cancer screening. Med J Aust. 2000;172:428-30.

33. O'Leary BA, Olynyk JK, Neville AM, Platell CF. Cost-effectiveness of colorectal cancer screening: comparison of community-based flexible sigmoidoscopy with fecal occult blood testing and colonoscopy. J Gastroenterol Hepatol. 2004;19:38-47.

34. Patel K, Hoffman NE. The anatomical distribution of colorectal polyps at colonoscopy. J Clin Gastroenterol. 2001;33:222-5.

35. Podolsky DK. Going the distance - the case for true colorectal-cancer screening. N Engl J Med. 2000;343:207-8.

36. Provenzale D, Garrett JW, Condon SE, Sandler RS. Risk for colon adenomas in patients with rectosigmoid hyperplastic polyps. Ann Intern Med. 1990;113:760-3.

37. Rabeneck L, Davila JA, El-Serag HB. Is there a true "shift" to the right colon in the incidence of colorectal cancer? Am J Gastroenterol. 2003;98:1400-9.

38. Ransohoff DF, Sandler RS. Clinical practice. Screening for colorectal cancer. N Engl J Med. 2002;346:40-4

39. Read TE, Read JD, Butterly LF. Importance of adenomas $5 \mathrm{~mm}$ or less in diameter that are detected by sigmoidoscopy. N Engl J Med. 1997;336:8-12.

40. Rex DK, Lehman GA, Hawes RH, Ulbright TM, Smith JJ. Screening colonoscopy in asymptomatic average-risk persons with negative fecal occult blood tests. Gastroenterology. 1991;100:64-7.

41. Rex DK, Smith JJ, Ulbright TM, Lehman GA. Distal colonic hyperplastic polyps do not predict proximal adenomas in asymptomatic average risk subjects. Gastroenterology. 1992;102:317-9.

42. Rex DK, Lehman GA, Ulbright TM, Smith JJ, Pound DC, Hawes RH, Helper DJ, Wiersema MJ, Langefeld CD, Li W. Colonic neoplasia in asymptomatic persons with negative fecal occult blood tests: influence of age, gender, and family history. Am J Gastroenterol. 1993;88:825-31.

43. Rex DK, Chak A, Vasudeva R, Gross T, Lieberman D, Bhattacharya I, Sack E, Wiersema M, Farraye F, Wallace M, Barrido D, Cravens E, Zeabart L, Bjorkman D, Lemmel T, Buckley S. Prospective determination of distal colon findings in average-risk patients with proximal colon cancer. Gastrointest Endosc. 1999;49:727-30.

44. Rex DK, Khan AM, Shah P, Newton J, Cummings OW. Screening colonoscopy in asymptomatic average-risk African Americans. Gastrointest Endosc. 2000;51:524-7.

45. Rex DK, Lieberman DA. Feasibility of colonoscopy screening: discussion of issues and recommendations regarding implementation. Gastrointest Endosc. 2001;54:662-7.

46. Sciallero S, Costantini M, Bertinelli E, Castiglione G, Onofri P, Aste H, Casetti T, Mantellini P, Bucchi L, Parri R, Boni L, Bonelli L, Gatteschi B, Lanzanova G, Rinaldi P, Giannini A, Naldoni C, Bruzzi P. Distal hyperplastic polyps do not predict proximal adenomas: results from a multicentric study of colorectal adenomas. Gastrointest Endosc. 1997;46:124-30

47. Senore C, Segnan N, Bonelli L, Sciallero S, Pennazio M, Angioli D, Crosta C, Gasperoni S, Malfitana G. Predicting proximal advanced neoplasms at screening sigmoidoscopy. Dis Colon Rectum. 2004;47:1331-40.

48. Simons BD, Morrison AS, Lev R, Verhoek-Oftedahl W. Relationship of polyps to cancer of the large intestine. J Natl Cancer Inst. 1992;84:962-6.

49. Sung JJ, Chan FK, Leung WK, Wu JC, Lau JY, Ching J, To KF, Lee YT, Luk YW, Kung NN, Kwok SP, Li MK, Chung SC. Screening for colorectal cancer in Chinese: comparison of fecal occult blood test, flexible sigmoidoscopy, and colonoscopy. Gastroenterology. 2003;124:608-14

50. UK Flexible Sigmoidoscopy Screening Trial Investigators. Single flexible sigmoidoscopy screening to prevent colorectal cancer: baseline findings of a UK multicentre randomised trial. Lancet. 2002;359:1291-300.

51. Villavicencio RT, Rex DK. Colonic adenomas: prevalence and incidence rates, growth rates, and miss rates at colonoscopy. Semin Gastrointest Dis. 2000;11:185-93.

52. Winawer SJ, Zauber AG, Ho MN, O'Brien MJ, Gottlieb LS, Sternberg SS, Waye JD, Schapiro M, Bond JH, Panish JF. Prevention of colorectal cancer by colonoscopic polypectomy. The National Polyp Study Workgroup. N Engl J Med. 1993;329:1977-81. 